\title{
KAPITAL LUDZKI, CECHY PRACOWNIKA, STANOWISKO, CZY ORGANIZACJA? UWARUNKOWANIA SZKOLEŃ PRACOWNIKÓW W ŚWIETLE WYNIKÓW WYBRANYCH BADAŃ
}

\begin{abstract}
Streszczenie
Celem artykułu jest zaprezentowanie przeglądu literatury, w której omówiono czynniki wpływające na występowanie szkoleń i sposób ich oddziaływania, a także stworzenie na tej podstawie zestawienia obejmującego najważniejsze ze wspomnianych czynników wraz ze spodziewanym wpływem na prawdopodobieństwo uczestnictwa pracowników w szkoleniu. Przyjmując za podstawę rozważań teorię kapitału ludzkiego, teorię dyskryminacji statystycznej i teorie segmentacji rynku pracy, wyróżniono cztery grupy czynników wpływających na szkolenia pracowników: związane z: kapitałem ludzkim pracownika, jego cechami osobistymi, specyfiką wykonywanej pracy oraz uwarunkowaniami organizacyjnymi. Opierając się na dotychczasowych wynikach badań oraz refleksji teoretycznej, wyjaśniono sposób oddziaływania wyróżnionych grup czynników na występowanie szkoleń pracowniczych. We wnioskach końcowych przedstawiono możliwości wykorzystania zaprezentowanej analizy w dalszych badaniach.
\end{abstract}

Słowa kluczowe: uwarunkowania szkoleń, teoria kapitału ludzkiego, teoria dyskryminacji statystycznej, teorie segmentacji rynku pracy

\section{HUMAN CAPITAL, EMPLOYEE CHARACTERISTICS, POSITION OR ORGANISATION? THE DETERMINANTS OF EMPLOYEE TRAINING IN LIGHT OF SELECTED STUDIES}

\section{Summary}

The aim of the paper is to present a review of the literature concerned with factors behind the occurrence of professional training courses and their influence, and to list the most important factors and their predicted impact on training participation probability. With human capital theory, statistical discrimination theory and labour market segmentation theories as a premise for the analysis, on the basis of the literature review, four groups of employee training determinants were distinguished: those connected with employees' human capital, their personal traits, the nature of the job, and the organisational circumstances. Referring to prior research as well as theoretical reflection, the way in which these factors influence the occurrence of training is explained. The concluding section contains suggestions regarding the application of the presented analysis in further research.

Key words: training determinants, human capital theory, statistical discrimination theory, labour market segmentation theories

\footnotetext{
${ }^{1}$ Mgr Przemysław Piasecki - Wydział Ekonomii, Uniwersytet Ekonomiczny w Poznaniu; e-mail: przemyslaw.piasecki@ue.poznan.pl.
} 


\section{Wstęp}

Problematyka szkoleń jest coraz częściej podejmowana z perspektywy różnych dyscyplin naukowych, a wyniki badań wskazują, że odpowiednio przygotowane i przeprowadzone szkolenia przynoszą organizacji pozytywne efekty [Salas i in. 2012]. Jednocześnie zmiany zachodzące na rynku pracy wymuszają na pracownikach nieustanne dążenie do zdobywania nowych umiejętności i rozwijania już posiadanych [Szczucka, Turek, Worek, 2014, s. 77]. Szkolenia są zatem obiektem zainteresowań zarówno kierownictw organizacji, jak i samych zatrudnionych [Andrzejczak, 2010, s. 85].

Jak wskazują Boxall, Ang i Bartram [Boxall, Ang, Bartram, 2011], w badaniach systemów zarządzania zasobami ludzkimi (ZZL) występujących w organizacjach można wyróżnić dwa podstawowe nurty - pierwszy dotyczący wpływu praktyk ZZL na wyniki podmiotów gospodarczych i drugi podejmujący rozważania na temat uwarunkowań występowania określonych praktyk. Do pewnego stopnia podział ten można odnieść do obszaru szkoleń, rozpatrując je z punktu widzenia zwrotu z inwestycji szkoleniowej [np. Pfeifer i in. 2011], jak również czynników, które wpłynęły na wystąienie, intensywność, zróżnicowanie oraz sposób finansowania procesu rozwoju kompetencji pracowników. W niniejszym artykule podjęto drugi z wymienionych nurtów, tzn. analizie poddano czynniki oddziałujące na wystąpienie szkoleń, najczęściej uwzględniane w literaturze przedmiotu.

Celem artykułu jest zaprezentowanie przeglądu literatury, w której omówiono czynniki wpływające na występowanie szkoleń i sposób ich oddziaływania (w perspektywie wybranych teorii), a także stworzenie na tej podstawie zestawienia obejmującego najważniejsze ze wspomnianych czynników wraz ze spodziewanym wpływem na prawdopodobieństwo uczestnictwa pracowników w szkoleniu. Podstawowe pytanie badawcze sformułowano w następujący sposób: jakie czynniki (cechy pracowników i organizacji) i w jaki sposób (wzrost lub spadek prawdopodobieństwa) oddziałują na uczestnictwo pracowników w szkoleniach?

\section{Szkolenia w świetle różnych perspektyw teoretycznych}

Jak podkreśla Andrzejczak [Andrzejczak, 2010, s. 84], wielu autorów przyjmuje bardzo różne definicje szkolenia, np. stosując je zamiennie z terminem rozwój lub uznając nadrzędność drugiego $z$ wymienionych pojęć nad pierwszym. Ze względu na analizę uwarunkowań szkoleń pracowników nie bez znaczenia jest to, które formy rozwoju kompetencji uznane zostaną za szkolenia, gdyż może to być związane np. $z$ ich kosztownościa, ta zaś z horyzontem czasowym zwrotu z inwestycji (por. dalej w kontekście wieku). Na potrzeby niniejszego artykułu za szkolenie uznano: proces rozwijamia ogólnych kewalifikagi zawodonych, usyskanych $w$ trakcie ksztatcenia w formach szkolmych $i$ dotychczasowej praktyki zawodowej, w celu dopasowania ich do zmieniajacych sie uymagań zwiazanych ze stanowiskiem pracy i do wtasnych aspiracji [Andrzejczak, 1999 za: Andrzejczak, 2010].

Petridou i Spathis [Petridou, Spathis, 2001] wyróżniają dwa podejścia do analizy czynników oddziałujących na uczestnictwo pracowników w szkoleniu: z punktu wi- 
dzenia rynku pracy - bazujące na teorii kapitału ludzkiego (TKL) oraz psychologiczne - bazujące na postawach pracowników wobec szkolenia i środowiska w miejscu pracy. W niniejszym artykule zastosowano pierwsze z wymienionych podejść, tzn. jako ramy teoretyczne przyjęto Teorię Kapitału Ludzkiego (TKL). Warto zaznaczyć, że TKL stanowi dominująca perspektywą teoretyczna, służącą analizie rozwoju pracowników na gruncie ekonomii [Nisar, 2004; Leuven, 2005], jest również wykorzystywana w badaniach dotyczących szkoleń umiejscowionych w naukach o zarządzaniu [np.: Mainga, Hirschsohn, Shakantu, 2009; Grund, Martin, 2012]².

Według TKL, szkolenia są formą inwestycji w kapitał ludzki (KL) pracowników, która jest związana z ponoszeniem kosztów i która w przyszłości ma przynieść korzyści w postaci ich zwiększonej produktywności. Teoria Kapitału Ludzkiego w swej pierwotnej postaci wyróżnia dwa typy KL: ogólny obejmujący umiejętności transferowalne, tzn. będące użytecznymi w wielu miejscach pracy i specyficzny, do którego należą umiejętności nietransferowalne, tzn. dające się wykorzystać jedynie u pracodawcy, u którego zostały wykształcone [Becker, 1993, s. 33-51]. Rozróżnienie to skutkuje odmiennymi wskazaniami teorii w zakresie finansowania kosztów szkolenia pracowników pracodawca powinien ponosić koszty wyłącznie szkoleń o charakterze specyficznym, gdyż w przeciwnym razie naraża się na utratę korzyści z poniesionych wydatków związaną z odejściem pracownika. Co więcej, organizacja powinna inwestować jedynie w pracowników charakteryzujących się odpowiednim poziomem zdolności umożliwiającym osiagnięcie określonego zwrotu z inwestycji w KL [Acemoglu, Pischke, 1998], stąd podstawowym kryterium inwestycji w KL pracowników powinny być cechy KL pracowników³

Jednak wielu autorów modyfikowało restrykcyjne założenia podstawowej wersji TKL, starając się wyjaśnić m.in. występujące niejednokrotnie inwestycje pracodawców w rozwój umiejętności zatrudnionych osób o charakterze ogólnym, poprzez wprowadzenie do modeli elementów, takich jak: niedoskonała konkurencja, asymetria informacji lub koszty transakcyjne [Leuven, 2005]. Przykładowo uwzględnienie problemu asymetrii informacji rzuca nowe światło na decyzje kierownictw firm dzięki wprowadzeniu do analizy elementu ryzyka dotyczącego braku wiedzy o tym, jak długo podwładny będzie związany z firmą oraz w jakim wymiarze czasu pracy (pełny lub niepełny etat) będzie pracować. Obie wymienione zmienne maja istotny wpływ na horyzont czasowy zwrotu $\mathrm{z}$ inwestycji w KL (liczony godzinami pracy). Próbując poradzić sobie z tym problemem, pracodawca może posługiwać się przybliżeniami opartymi na postrzeganej przez niego przynależności pracownika do pewnych grup społecznych, o których posiada (mniej lub bardziej wiarygodne) informacje dotyczące ich aktywności i mobilności zawodowej, np. wyróżnionych ze względu na płeć lub wiek. W ten sposób w perspektywę TKL można wpleść elementy opisane przez teorię dyskryminacji statystycznej [Backes-Gellner, Oswald, Tuor, 2011]. Innym przykładem są ograniczenia mobil-

2 Model podejmowania decyzji o uczestnictwu w szkoleniach oparty na innej podstawie teoretycznej prezentują np.: Kawecka, Łaguna i Tabor [Kawecka, Laguna, Tabor, 2010].

${ }^{3}$ Przykładem takich cech moga być: wartość i unikatowość KL pracowników wykorzystywane w modelu Architektury Zasobów Ludzkich [Lepak, Snell, 1999]. 
ności pracowników, które mogą sprawiać, że będą oni bardziej lub mniej skłonni do opuszczenia firmy, niż wskazywałoby na to ich wyposażenie w ogólny i specyficzny KL [Asplund, 2005]. W tym przypadku można wymienić zarówno podażowe (wynikajace z podaży pracy pracowników na zewnętrznym rynku pracy) ograniczenia mobilności, takie jak materialne i emocjonalne koszty mobilności, jak i popytowe (wynikające z popytu na pracę pracowników zgłaszanego przez firmy-konkurentów) ograniczenia mobilności mogące wyrazić się m.in. stygmatyzacją pracowników o określonych cechach [Campbell, Coff, Kryscynsky, 2012]. W wyniku uwzględnienia tych czynników można wskazać zmienne mające znaczenie dla decyzji o inwestycji w rozwój pracownika, np. jego satysfakcję z pracy lub posiadanie dzieci, które powinny zwiększać jego koszty mobilności. Do analizy szkoleń są również wprowadzane instytucje, które zaburzają „czysty” model TKL, np.: zwiazki zawodowe, płace minimalne, regulacje dotyczace rynku produktów i system podatkowy [Bassanini i in. 2005], tym samym ponownie rozbudowując listę czynników mogących mieć wpływ na uczestnictwo pracowników w procesie rozwoju kompetencji. Interesująca perspektywą teoretyczną wyjaśniającą uczestnictwo pracowników w szkoleniach, jest w zwiazku z tym grupa teorii segmentacji rynku pracy, która stanowi kontrpropozycję wobec TKL, wskazując, że warunki pracy - w tym uczestnictwo w szkoleniach - mogą być w dużej mierze zdeterminowane uwarunkowaniami instytucjonalnymi, a nie cechami KL pracowników [Leontaridi, 1998].

\section{Czynniki wpływające na uczestnictwo pracowników w szkoleniach}

Jak wskazują powyższe przykłady, oprócz TKL niezbędne są inne perspektywy teoretyczne uzasadniające wpływ różnych czynników na szkolenie pracowników. W niniejszym artykule zbiór czynników oddziałujących na występowanie szkoleń oparto przede wszystkim na trzech przeglądach badań [Green, 1993; Blundell, Dearden, Meghir, 1996; Shields, 1998], rozbudowując stworzoną na ich podstawie listę o te zmienne, które najczęściej pojawiały się w przeglądzie literatury dokonanym przez autora ${ }^{4}$, a jednocześnie wpisują się w perspektywę TKL, teorii dyskryminacji statystycznej lub teorii segmentacji rynku pracy.

W literaturze przedmiotu czynniki wpływające na uczestnictwo pracowników w szkoleniach były klasyfikowane - w zależności od autorów - w dwie [np. Renaud, Lakhdari, Morin, 2004], trzy [np. Shields, 1998] lub cztery grupy [np. Bassanini i in. 2005]. W niniejszym artykule zastosowano podział na cztery grupy, dla których wyróżniono

\footnotetext{
${ }^{4}$ Analiza literatury polegała przede wszystkim na wyszukaniu czasopism obcojęzycznych za pomoca wyszukiwarki EBSCO (przy uwzględnieniu wyłącznie pozycji pełnotekstowych i pochodzaccych z czasopism naukowych oraz zawierających w tytule słowa: determinants oraz training). Wyróżniono 25 pozycji, z których 13 rzeczywiście dotyczyło czynników wpływających na występowanie szkoleń. Przegląd literatury krajowej uwzględniał analizę tytułów artykułów zawartych w czasopismach: „Optimum. Studia Ekonomiczne”, „Organizacja i Kierowanie”, „Problemy Zarządzania” oraz „Zarządzanie Zasobami Ludzkimi” w latach 2009-2014. Do otrzymanych wyników dołączono inne pozycje, podejmujące problematykę uwarunkowań występowania szkoleń [np.: Szczucka, Turek, Worek, 2014].
} 
najczęściej występujące w literaturze czynniki oddziałujące na występowanie szkoleń wraz ze wskazaniem przewidywanego kierunku ich oddziaływania (por. tabela 1.).

TABELA 1.

Cztery grupy czynników oddziałujących na uczestnictwo pracowników w szkoleniach w świetle: teorii kapitału ludzkiego, teorii dyskryminacji statystycznej oraz teorii segmentacji rynku pracy

\begin{tabular}{|c|c|c|}
\hline $\begin{array}{l}\text { Grupa czyn- } \\
\text { ników }\end{array}$ & Przykładowe czynniki & $\begin{array}{c}\text { Spodziewany wpływ na prawdo- } \\
\text { podobieństwo uczestnictwa } \\
\text { w szkoleniu } \\
\text { (,+”- pozytywny, ,-”- negatywny, } \\
\text { „?”- trudny do przewidzenia) }\end{array}$ \\
\hline \multirow{3}{*}{$\begin{array}{c}\text { Cechy kapi- } \\
\text { tału ludzkie- } \\
\text { go pracowni- } \\
\text { ka }\end{array}$} & poziom wykształcenia & + \\
\hline & staż pracy u danego pracodawcy & $\begin{array}{c}?(+/-/ \text { może występować punkt mini- } \\
\text { mum })\end{array}$ \\
\hline & poziom umiejętności & + \\
\hline \multirow{7}{*}{$\begin{array}{l}\text { Cechy osobi- } \\
\text { ste pracowni- } \\
\text { ka }\end{array}$} & kobieta & $?(+/-)$ \\
\hline & wiek & $\begin{array}{c}\text { ? (-/ może występować punkt maksi- } \\
\text { mum) }\end{array}$ \\
\hline & pozostawanie w związku małżeńskim & + \\
\hline & posiadanie dzieci na utrzymaniu & - \\
\hline & wieś jako miejsce zamieszkania & - \\
\hline & przynależność do mniejszości narodowej & - \\
\hline & przynależność do związku zawodowego & + \\
\hline \multirow{4}{*}{$\begin{array}{c}\text { Cechy wyko- } \\
\text { nywanej pra- } \\
\text { cy }\end{array}$} & $\begin{array}{c}\text { zawód o wysokich wymaganiach kwalifika- } \\
\text { cyjnych }\end{array}$ & + \\
\hline & pozycja kierownicza & + \\
\hline & praca w pełnym wymiarze czasu pracy & + \\
\hline & długookresowy kontrakt zatrudnienia & + \\
\hline \multirow{5}{*}{$\begin{array}{l}\text { Cechy orga- } \\
\text { nizacji }\end{array}$} & wielkość firmy & + \\
\hline & branża zaawansowanych technologii & + \\
\hline & poziom rotacji pracowników & - \\
\hline & poziom bezrobocia $\mathrm{w}$ regionie & - \\
\hline & sektor publiczny & + \\
\hline
\end{tabular}

Źródło: opracowanie własne na podstawie: [Green, 1993; Blundell, Dearden, Meghir, 1996; Oosterbeek, 1998; Shields, 1998; Harris, 1999; Leuven, Oosterbeek, 1999; Nisar, 2004; Renaud, Lakhdari, Morin, 2004; Almeida-Santos, Mumford, 2005; Asplund, 2005; Bassanini i in. 2005; Litwiński, 2007; Franck, Nüesch, Pieper, 2009; Backes-Gellner, Oswald, Tuor, 2011; Thangavelua i in. 2011; Grund, Martin, 2012; Szczucka, Turek, Worek, 2014].

Przyjęcie perspektywy TKL przede wszystkim nasuwa cechy KL pracownika jako czynniki oddziałujące na jego uczestnictwo w szkoleniach. Ponieważ pracodawca chętniej szkoli osoby charakteryzujące się pewnymi zdolnościami [Pfeifer i in. 2011] trudnymi do zaobserwowania, dla których - w jego ocenie - zwrot z poniesionej inwestycji będzie większy, będzie szukał możliwości ich oceny, posiłkując się obserwowalnymi zmiennymi, które w jego odczuciu są sygnałami o uzdolnieniach pracowników, np. wykształceniem [Oosterbeek, 1998]. Nic zatem dziwnego, że lepiej wykształceni pracownicy otrzymują więcej szkoleń [Nisar, 2004; Boni, 2007; Szczucka, Turek i Worek, 2014, s. 84]. Co więcej, pracownicy z wyższym poziomem wykształcenia sami mogą zgłaszać większe zapotrzebowanie na szkolenia, oczekując wyższego zwrotu z tej inwestycji [Oosterbeek, 
1998]. Miernikiem KL, używanym niejednokrotnie w badaniach, jest również staż pracy [np. Franck, Nüesch, Pieper, 2009], przy czym niektórzy autorzy dziela go na całkowity staż pracy oraz staż pracy u danego pracodawcy, uznając, że pierwszy jest synonimem ogólnego, a drugi specyficznego KL [np. Bassanini i in., 2005]. Wpływ stażu pracy na występowanie szkoleń jest niejednoznaczny - część badaczy wskazuje, że wraz ze stażem pracy rośnie prawdopodobieństwo uczestnictwa w szkoleniu [Nisar, 2004], inni uważają że spada [Blundell, Dearden, Meghir, 1996; Shields, 1998], jeszcze inni, że na wykresie funkcji staż pracy - szkolenia można wyróżnić pewien punkt minimum, tzn. w pewnym okresie zatrudnienia prawdopodobieństwo szkolenia jest najmniejsze [Bassanini i in., 2005; Grund, Martin, 2012]. Kolejną zmienną obrazująca poziom KL są umiejętności posiadane przez pracownika [Veum, 1995], jednak należy pamiętać, że, aby móc włączyć je do analizy, należałoby dokonać ich pomiaru przed pomiarem wystapienia szkolenia, a także uwzględnić korelację z innymi miarami opisującymi KL pracownika ${ }^{5}$. Czynnikiem, który może mieć istotne znaczenie dla występowania inwestycji w KL, są również ograniczenia mobilności [Rinawi, Backes-Gellner, 2013]. Zazwyczaj przyjmuje się, że specyficzność KL jest wystarczającą barierą ograniczającą mobilność pracowników, tzn. zmniejszająca ryzyko utraty KL dla firmy, lecz, jak wskazują Campbell, Coff i Kryscynsky [Campbell, Coff, Kryscynsky, 2012], może okazać się, że występujące na rynku pracy popytowe i podażowe ograniczenia mobilności będą oddziaływały na decyzję pracownika silniej, niż kalkulacja oparta na specyficzności KL. Przykładowo Backes-Gellner i Mure [Backes-Gellner, Mure, 2005] wskazują, że im więcej ofert ma pracownik na zewnątrz, tym mniej chętnie firma inwestuje w jego KL. Jednak w literaturze przedmiotu niejednokrotnie nie wyróżnia się ograniczeń mobilności pracowników jako osobnego czynnika - są one bowiem „ukryte” w różnych uwarunkowaniach związanych z wykonywana pracą oraz sytuacją życiowa pracowników, które znalazły się w tabeli 1 ., np. w posiadaniu dziecka na utrzymaniu lub wysokim poziomie bezrobocia w regionie ${ }^{6}$.

W praktyce, poza cechami KL, pracodawca może również zwracać uwagę na inne cechy pracownika przy podejmowaniu decyzji o inwestycji w jego KL. Jedną z nich jest płeć, choć badania nie daja jednoznacznej odpowiedzi, w jakim kierunku koreluje ona ze szkoleniami. Przykładowo, według Oosterbeeka [Oosterbeek, 1998], kobiety mniej uczestniczą w szkoleniach, a Blundell, Dearden i Meghir [Blundell, Dearden, Meghir, 1996] wskazuja, że mają do nich gorszy dostęp, natomiast w innym badaniu [Bassanini i in. 2005] okazało się, że kobiety mają ceteris paribus, wyższe prawdopodobieństwo uczestnictwa w szkoleniach (choć fakt, że często same płaciły za podnoszenie swoich kwalifikacji, miał w tym przypadku niemałe znaczenie). Z drugiej strony kobiety mogą być bardziej przywiązane do swojego pracodawcy, co powinno się przekładać na niższe ryzyko nagłego odejścia pracownika z organizacji [Nisar, 2004].

${ }^{5}$ W przypadku badania Oosterbeeka [Oosterbeek, 1998] okazało się, że zmienna opisująca umiejętności jest silnie skorelowana z poziomem wykształcenia.

${ }^{6}$ Do innych czynników związanych z ograniczaniem mobilności pracownika można zaliczyć np.: sytuację finansowa, materialne (wynagrodzenie) i niematerialne (np. satysfakcja) korzyści z pracy, rozpoznawalność KL na rynku pracy. 
Wiek również może wpływać na inwestycje pracodawcy w KL pracowników, jednak - podobnie jak w odniesieniu do płci - związek pomiędzy tą zmienną a występowaniem szkoleń jest niejednoznaczny. W badaniu Pfeifera i innych [Pfeifer i in. 2012] wykazano, że relacje wiek-intensywność szkoleń obrazuje odwrócona litera U, co oznacza, że najwięcej szkoleń otrzymuja pracownicy w średnim wieku (wniosek odwrotny do przedstawionego wcześniej w kontekście stażu pracy). Na taki kształt relacji wskazują również: Litwiński [Litwiński, 2007], Grund i Martin [Grund, Matin, 2012] oraz Szczucka, Turek i Worek [Szczucka, Turek, Worek, 2014, s. 86]. Inni autorzy uważaja natomiast, że starsi otrzymują mniej szkoleń [np. Boni, 2007], m.in. z powodu krótszego w stosunku do ludzi młodych horyzontu zwrotu z inwestycji [Oosterbeek, 1998]. Innymi czynnikami osobistymi, wpływającymi na wystąienie szkoleń, sa: posiadanie współmałżonka [Bassanini i in. 2005], w szczególności pracującego [Michaelides, 2010] oraz posiadanie dzieci [Almeida-Santos, Mumford, 2005; Michaelides, 2010] posiadanie niepełnosprawnego dziecka. Oba czynniki obniżają mobilność, co powinno zachęcać pracodawców do inwestowania w KL pracowników, lecz w przypadku posiadania dzieci na utrzymaniu możliwa jest - zwłaszcza w odniesieniu do kobiet - mniejsza koncentracja na karierze zawodowej, a stąd mniejsza chęć do uczestnictwa w szkoleniach. Posiadanie dzieci może także, podobnie jak płeć, być dla pracodawcy wskaźnikiem przyszłej aktywności zawodowej. Posiadanie większej liczby dzieci może w oczach pracodawcy być związane z chęcią ograniczenia aktywności zawodowej, a zatem zmniejszenia jego potencjalnych korzyści uzyskiwanych z podnoszenia kwalifikacji pracowników (teoria dyskryminacji statystycznej), [Shields, 1998]. Jako kolejne uwarunkowania szkolenia pracowników można wymienić: miejsce zamieszkania, narodowość i przynależność do związku zawodowego. Jak wskazują Szczucka, Turek i Worek [Szczucka, Turek, Worek, 2014, s. 104-105], mieszkańcy wsi, wedle wyników ich badań, mają dużo niższe prawdopodobieństwo uczestnictwa w szkoleniu, niż mieszkańcy dużych i średnich miast. Podobne wnioski nasuwają wyniki innych badań [Boni, 2007]. Narodowość może być związana z różną aktywnością na rynku pracy [Oosterbeek, 1998] i - podobnie jak płeć - być traktowana jako wyznacznik przyszłej produktywności [Harris, 1999]. Jak wskazują Leuven i Oosterbeek [Leuven, Oosterbeek, 1999], zamieszkiwanie obszarów miejskich oraz kraju pochodzenia przekłada się na silniejszą pozycję na rynku pracy, a ta z kolei może wiązać się z większym prawdopodobieństwem szkolenia (teorie segmentacji rynku pracy). W stosunku do przynależności do związku zawodowego wpływ na wystąpienie szkoleń wydaje się być z pozoru niejednoznaczny. Pracownicy w związkach zawodowych są mniej skłonni do odejścia z firmy [Anderson, Butler, Sloan, 1987], a stąd powinni częściej brać udział w szkoleniach, z drugiej strony obecność związków zawodowych powoduje zmniejszenie zróżnicowania poziomu wynagrodzeń w organizacji, co może skutkować mniejszym zainteresowaniem pracowników szkoleniami [Bassanini i in., 2005]. Jednak w drugim przypadku sama przynależność do związku zawodowego nie będzie miała większego znaczenia, dlatego można przyjąć, że cecha ta będzie pozytywnie korelowała z uczestnictwem w szkoleniach.

Także cechy samej pracy i kontraktu zatrudnienia mogą mieć znaczenie dla występowania szkoleń. Grupy pracowników o różnym umiejscowieniu w hierarchii oraz typie wykonywanej pracy są w odmienny sposób zarządzane w zakresie ZZL [Boxall, Ang, 
Bartram, 2011]. Bassanini i innni [Bassanini i in. 2005] wskazuja, że szkolenia są częstsze na stanowiskach wymagających wysokich kwalifikacji, do podobnych wniosków dochodzi Litwiński [Litwiński, 2007]. Co więcej, niektóre zawody mogą charakteryzować się wysoką standaryzacją informacji o dotychczasowym doświadczeniu zawodowym i wykształceniu, np. w postaci dyplomów i certyfikatów. Informacja taka ułatwia pracodawcom ocenę KL posiadanego przez kandydatów do pracy, a w związku z tym zmniejsza ograniczenia mobilności pracowników [Ferrary, 2002], czego efektem jest mniejsza chęć pracodawców do inwestowania w KL pracownika. Tak jak w przypadku stanowisk wymagających wysokich kwalifikacji, pracownicy, którzy są umiejscowieni wyżej w hierarchii organizacyjnej, otrzymuja zazwyczaj więcej szkoleń [Oosterbeek, 1998; Asplund, 2005; Szczucka, Turek, Worek, 2014, s. 84]. Wymiar etatu oraz typ kontraktu moga również mieć istotne znaczenie dla inwestycji pracodawcy w KL pracowników. Pracownicy zatrudnieni czasowo lub w niepełnym wymiarze moga nie być objęci tak intensywnymi praktykami ZZL, jak inni [Oosterbeek, 1998; Bassanini i in. 2005], co podobnie jak w odniesieniu do kobiet - może być rezultatem kalkulacji spodziewanej aktywności zawodowej (liczby godzin pracy) po szkoleniu. Jednocześnie zatrudnieni na kontraktach stałych charakteryzują się mniejszym prawdopodobieństwem odejścia i stąd firma jest bardziej skłonna zainwestować w ich rozwój [Oosterbeek, 1998].

Czwarta grupą czynników oddziałujących na szkolenia występujące w firmie są czynniki związane z samą organizacja. Wielkość firmy jest powiązana ze stosowanymi praktykami ZZL [np. van de Woestyne, Dewettinck, van Bruystegem, 2010], m.in. większe przedsiębiorstwa szkolą intensywniej, niż małe [Bassanini i in. 2005; Oosterbeek, 1998]. Może to wynikać z: występowania pewnych kosztów stałych związanych z organizacją szkolenia, a stąd ekonomią skali, trudnością w zastąpieniu czasowo nieobecnego pracownika małej firmy poświęcającego czas na szkolenie oraz mniejszymi możliwościami wykorzystania efektów podnoszenia kwalifikacji przez wewnętrzną realokację pracowników przy ograniczonej wielkości załogi [Bassanini i in. 2005]. Branża zaawansowanych technologii sprzyja inwestowaniu w rozwój pracowników, co można tłumaczyć m.in. poziomem innowacyjności przedsiębiorstwa, który, jak zauważają Oosterbeek [Oosterbeek, 1998] oraz Szczucka, Turek i Worek [Szczucka, Turek, Worek, 2014, s. 92], powinien być pozytywnie skorelowany z występowaniem w niej szkoleń. Warto jednak zauważyć, że nie wszystkie wyniki badań jednoznacznie wskazują, w przypadku których branż uczestnictwo pracowników w szkoleniach jest większe [Shields, 1998]. Na występowanie szkoleń powinna mieć również wpływ rotacja pracowników - zgodnie z TKL rotacja powinna być negatywnie skorelowana z inwestycjami w KL pracowników przede wszystkim o charakterze specyficznym [np. Acemoglu, Pischke, 1998; Asplund, 2005], przy czym możliwe jest, że zależność pomiędzy rotacją a szkoleniami przebiega dwustronnie, tzn. nie tylko intensywność rozwoju kompetencji pracowników jest uzależniona od rotacji, ale także wprowadzenie szkoleń ogranicza ro- 
tację ${ }^{7}$ [Flaherty, 2007]. Trudności w pozyskaniu pracowników również mogą sprawiać, że firma zdecyduje się na bardziej intensywne szkolenia [np. Almeida-Santos, Mumford, 2005] - w sytuacji niedoborów odpowiednich kompetencji na zewnętrznym rynku pracy będzie to sposób na wytworzenie ich we wnętrzu organizacji [Li, Sheldon, 2010]. Patrząc z tej perspektywy, poziom bezrobocia na lokalnym rynku pracy może stanowić czynnik oddziałujący na występowanie i intensywność szkoleń w organizacji [Veum, 1995]. Almeida-Santos i Mumford [Almeida-Santos, Mumford, 2005] przyjmują trudność w znalezieniu odpowiednich kandydatów oraz poziom bezrobocia na lokalnym rynku pracy jako mierniki szans na zatrudnienie w innym niż aktualne miejscu pracy, co bezpośrednio wiąże się z chęcia pracodawcy do inwestowania w KL podwładnych. Ostatnim $z$ wymienionych $w$ tabeli 1 . czynników wpływających na zróżnicowanie intensywności szkoleń między organizacjami jest sektor [np. Oosterbeek, 1998]. Organizacje sektora publicznego szkola pracowników bardziej intensywnie, niż podmioty w sektorze prywatnym, m.in. z powodu mniejszego ryzyka przejęcia pracowników przez konkurencję oraz mniejszej wrażliwości na zmiany gospodarcze zmuszające do zwalniania pracowników [Shields, 1998].

W literaturze można znaleźć obszerny katalog innych czynników, które niektórzy autorzy wymieniaja jako uwarunkowania występowania szkoleń, jednak pojawiają się one rzadziej niż te, które wymieniono w tabeli 1 . Wśród czynników związanych z cechami osobistymi pracownika można wymienić: poziom edukacji rodziców stanowiący przybliżenie pochodzenia społecznego [Oosterbeek, 1998], bycie głową rodziny i wielkość gospodarstwa domowego [Oosterbeek, 1998], sytuację finansowa [Greenhalgh, Mavrotas, 1994], postawy wobec samorozwoju i kariery [Greenhalgh, Mavrotas, 1994], a także posiadanie i poszukiwanie dodatkowego miejsca zatrudnienia [Harris, 1999]. W odniesieniu do cech organizacji, poza najczęściej pojawiającymi się w badaniach, stosowano również: sytuację finansową firmy (gdyż może ona oddziaływać na stosowane praktyki ZZL [Wright i in. 2005]), konkurencję, jakiej doświadcza firma, choć np. Arvanitis i Stucki [Arvanitis, Stucki, 2008] wskazują na brak zwiazku konkurencji ze skłonnością do szkoleń, tempo rozwoju firmy [Szczucka, Turek, Worek, 2014, s. 118-119], występowanie strategii prowzrostowej [de Kok, Uhlander, 2001] i nastawionej na rozwijanie zasobów ludzkich wewnątrz organizacji [Szczucka, Turek, Worek, 2014, s. 118-119, 123], posiadanie wielu oddziałów (może zmniejszać prawdopodobieństwo wystąpienia szkoleń, z uwagi na możliwość substytuowania ich przesunięciami pracowników pomiędzy poszczególnymi oddziałami w celu uzupełnienia luk kompetencyjnych w placówkach), [Nisar, 2004] oraz obecność specjalisty do spraw zasobów ludzkich (który pomaga odpowiednio kształtować praktyki ZZL, w ten sposób zwiększając prawdopodobieństwo uzyskania zadowalającego zwrotu z inwestycji w KL), [Almeida-Santos, Mumford, 2005].

\footnotetext{
${ }^{7}$ Podobna zależność występuje w wielu opisanych w niniejszym artykule relacjach, np. szkolenie jest uwarunkowane poziomem umiejętności pracowników, który rośnie w wyniku szkolenia.
} 


\section{Podsumowanie}

Analiza literatury odsłania ogromną różnorodność czynników, które mogą oddziaływać na występowanie szkoleń. Jednocześnie możliwe jest przedstawienie tych, które, wpisując się w przyjęte perspektywy teoretyczne, w dotychczasowych badaniach najczęściej występowały (choć kierunek ich oddziaływania nie zawsze był jednoznaczny). Ukazane zestawienie może stanowić punkt wyjścia zarówno do dalszych rozważań teoretycznych, jak i analiz empirycznych. Artykuł posiada także walor praktyczny, wskazując, jakie czynniki mogą być wzięte pod uwagę przez pracodawców zarządzających rozwojem pracowników w swoich organizacjach.

Wykorzystując analizę zaprezentowaną w badaniach empirycznych, należy pamiętać, że łączy ona popytowe (tzn. leżące po stronie pracownika) i podażowe (leżace po stronie kierownictwa organizacji) uwarunkowania szkoleń, a nie we wszystkich przypadkach chęć rozwijania kompetencji sygnalizowana przez jedną ze stron spotyka się z podobną postawa u drugiej strony [Greenhalgh, Mavrotas, 1994; Oosterbeek, 1998]. Co więcej, niektóre zmienne oddziałujące na występowanie szkoleń mogą być przypisane w równej mierze do podażowych, jak i popytowych czynników (np. sytuacja rodzinna [Oosterbeek, 1998]), podczas gdy inne tylko do jednej grupy (np. wielkość przedsiębiorstwa). Należy również pamiętać, że analiza uwarunkowań występowania szkoleń daje pełniejszy obraz, jeśli łączy się ją z badaniem ich intensywności [Castany, 2008]. Istotne jest także wzięcie pod uwage podziału na szkolenia opłacane przez pracodawcę i przez pracownika, gdyż w obu grupach intensywność oddziaływania różnych czynników może być zróżnicowana [Bassanini i in. 2005]. Podobnie uczestnictwo w różnych typach szkolenia może być zależne od zróżnicowanych uwarunkowań [Blundell, Dearden, Meghir, 1996].

Uwzględniając powyższe informacje, można zasugerować, że badania podejmujące problematykę uwarunkowań występowania szkoleń powinny koncentrować się na różnorodności szkoleń i kontekstów, w jakich są one analizowane, przykładowo w mniejszych przedsiębiorstwach [np. Castany, 2008] lub w sektorze publicznym [np. Petridou, Spathis, 2001] itp. Ponadto, poza perspektywą pracodawcy, warto mieć na względzie perspektywę pracownika, w tym jego motywację do uczestnictwa w szkoleniach.

\section{Literatura}

Acemoglu D., Pischke J. S. 1998 Why Do Firms Train? Theory and Evidence, „The Quarterly Journal of Economics", vol. 113, no. 1.

Almeida-Santos F., Mumford K. 2005 Empolyee training and wage compression in Britain, „The Manchester School”, vol. 73, no. 3, DOI 10.1111/j.1467-9957.2005.00449.x.

Anderson K. H., Butler J. S., Sloan F. A. 1987 Labor Market Segmentation: A Cluster Analysis of Job Groupings and Barriers to Entry, „Southern Economic Journal”, vol. 53, no. 3 .

Andrzejczak A. 2010 Projektowanie i realizacja sžkoleń, Polskie Wydawnictwo Ekonomiczne, Warszawa. 
Arvanitis S., Stucki T. 2008 Training Propensity of Start-ups in Switzerland - A Study Based on Data for the Start-up Cohort 1996-97, „Leading House Working Paper”, no. 35.

Asplund R. 2005 The Provision and Effects of Company Training: A Brief Review of the Literature, „Nordic Journal of Political Economy”, vol. 31.

Backes-Gellner U., Mure J. 2005 The Skill-Weights Approach on Firm Specific Human Capital: Empirical Results for Germany, „Institute for Strategy and Business Economics University of Zurich Working Paper", no. 113.

Backes-Gellner U., Oswald Y., Tuor S.N. 2011 Part-time work and employer provided training: boon to women and bane to men?, „Leading House Working Paper”, no. 58.

Bassanini A., Booth A., Brunello G., De Paola M., Leuven E. 2005 Workplace Training in Europe, „IZA Discussion Paper”, no. 1640.

Becker G. S. 1993 Human Capital. A Theoretical and Empirical Analysis with Special Reference to Education, 3rd ed., The University of Chicago Press, Chicago.

Blundell R., Dearden L., Meghir C. 1996 The Determinants and Effects of Work-Related Training in Britain, The Institute for Fiscal Studies, KKS Printing, London.

Boni M. 2007 Kto uczestniczy w szkoleniach? Struktura uczestników sžkoleń, [w:] Edukacja dla pracy. Raport o rozwoju społecznym, Program Narodów Zjednoczonych ds. Rozwoju, Warszawa.

Boxall P., Ang S. H., Bartram T. 2011 Analysing the Black Box' of HRM: Uncovering HR Goals, Mediators, and Outcomes in a Standardized Service Environment, ,Journal of Management Studies”, vol. 48, iss. 7, DOI 10.1111/j.1467-6486.2010.00973.x.

Campbell B.A., Coff R., Kryscynsky D. 2012 Rethinking Sustained Competitive Advantage from Human Capital, „Academy of Management Review”, vol. 37, no. 3, DOI 10.5465/amr.2010.0276.

Castany L. 2008 The Role of Firm Size in Training Provision Decisions: evidence from Spain, „Leading House Working Paper”, no. 28.

de Kok J., Uhlander L.M. 2001 Organization Context and Human Resource Management in the Small Firm, „Small Business Economics”, vol. 17, iss. 4, DOI 10.1023/ A:1012238224409.

Ferrary M. 2002 Conflicts of interest and games of power concerning the standardization of the workforce, ,Journal of Socio-Economics”, vol. 31, iss. 4.

Flaherty C. 2007 The Effect of Employer Provided General Training on Turnover: Examination of Tuition Reimbursement Programs, „SIEPR Discussion Paper”, no. 0625.

Franck E., Nüesch S., Pieper J. 2009 Specific Human Capital as a Source of Superior Team Performance, „Institute for Strategy and Business Economics University of Zurich Working Paper", no. 113.

Green F. 1993 The Determinants of Training of Male and Female Employees in Britain, „Oxford Bulletin of Economics and Statistics", vol. 55, no. 1, DOI 10.1111/j.14680084.1993.mp55001006.x.

Greenhalgh C., Mavrotas G. 1994 The Role of Career Aspirations and Financial Constraints in Individual Access to Vocational Training, „Oxford Economic Papers”, vol. 46, no. 4. 
Grund C., Martin J. 2012 Determinants of further training - evidence for Germany, „The International Journal of Human Resource Management", vol. 23, no. 17, DOI 10.1080/09585192.2011.654347.

Harris R. I. D. 1999 The determinants of work-related training in Britain in 1995 and the implications of employer size, „Applied Economics”, vol. 31, iss. 4, DOI 10.1080/000368499324165.

Kawecka K., Laguna M., Tabor K. 2010 Gotowości do podejmowania sžoleń i dalszego kesztatcenia. Proposycja ujecia teoretycznego i skal pomiaru, „Organizacja i Kierowanie”, nr $2(140)$.

Leontaridi M.R. 1998 Segmented labour markets: theory and evidence, „Journal of Economic Surveys", vol. 12, iss. 1, DOI: 10.1111/1467-6419.00048.

Lepak D.P., Snell S.A. 1999 The Human Resource Architecture: Toward a Theory of Human Capital Allocation and Development, „Academy of Management Review”, vol. 24, no. I, DOI 10.5465/AMR.1999.1580439.

Leuven E. 2005 The Economics Of Private Sector Training: A Survey Of The Literature, "Journal of Economic Surveys", vol. 19, no. 1, DOI 10.1111/j.0950-0804. 2005.00240.x.

Leuven E., Oosterbeek H. 1999 The Demand and Supply of Work-Related Training: Evidence From Four Countries, „Research in Labor Economics”, vol. 18.

Litwiński J. 2007 Prawdopodobieństwo udriału w s₹koleniach, [w:] Edukacja dla pracy. Raport o rozwoju spolecznym, Program Narodów Zjednoczonych ds. Rozwoju, Warszawa.

Li Y., Sheldon P. 2010 HRM lives inside and outside the firm: employers, skill shortages, and the local labour market in China, „The International Journal of Human Resource Management", vol. 21, no. 12, DOI 10.1080/09585192.2010.509623.

Mainga W., Hirschsohn P., Shakantu W. 2009 An exploratory review of the relationship between enterprise training and technology upgrading: evidence from South African manufacturing firms, „The International Journal of Human Resource Management”, vol. 20, no. 9, DOI 10.1080/09585190903142340.

Michaelides M. 2010 Labour market oligopsonistic competition: The effect of worker immobility on wages, „Labour Economics”, vol. 17, iss. 1, DOI 10.1016/j.labeco.2009.01.007.

Nisar T. M. 2004 E-learning in Public Organization, „Public Personnel Management”, vol. 33, no. 1, DOI 10.1177/009102600403300106.

Oosterbeek H. 1998 Unravelling Supply and Demand Factors in Work-Related Training, „Oxford Economic Papers”, vol. 50, no. 2.

Petridou E.N., Spathis C.T. 2001 Designing training intervention: buman or technical skills training?, „International Journal of Training and Development”, vol. 5, iss. 3, DOI 10.1111/1468-2419.00131.

Pfeifer C., Janssen S., Yang S., Backes-Gellner U. 2011 Effects of Training on Employee Suggestions and Promotions in an Internal Labor Market, ,Leading House Working Paper", no. 61.

Pfeifer C., Janssen S., Yang P., Backes-Gellner U. 2012 Training Participation of a Firm's Aging Workforce, „Leading House Working Paper”, no. 80.

Renaud S., Lakhdari M., Morin L. 2004 The Determinants of Participation in Non-Mandatory Training, „Relations Industrielles / Industrial Relations”, vol. 59, no. 4. 
Rinawi M., Backes-Gellner U. 2013 Should I stay or should I go? - The Effect of Performance Pay on the Retention of Apprenticeship Graduates, „Beiträge zur Jahrestagung des Vereins für Socialpolitik 2013: Wettbewerbspolitik und Regulierung in einer globalen Wirtschaftsordnung - Session: Training and Apprenticeship", no. D07-V1.

Salas E., Tannenbaum S.I., Kraiger K., Smith-Jentsch K.A. 2012 The Science of Training and Development in Organizations: What Matters in Practice, „Psychological Science in the Public Interest", vol. 13, no. 2, DOI 10.1177/1529100612436661.

Shields M. 1998 Changes in the determinants of employer-funded training for full-time employees in Britain, 1984-1994, „Oxford Bulletin of Economics and Statistics”, vol. 60, iss. 2, DOI 10.1111/1468-0084.00094.

Szczucka A., Turek K., Worek B. 2014 W ogonie Europy - uwarunkowania i strategie rozwoju kompetenciji dorostych Polaków, [w:] Kompetencje Polaków a potrzeby polskiej gospodarki. Raport podsumownjacy IV edycje badań BKL z 2013 roku, J. Górniak (red.), Polska Agencja Rozwoju Przedsiębiorczości, Warszawa.

Thangavelua S.M., Haominga L., Cheolsunga P., Boon Hengb A., Wongb J. 2011 The determinants of training participation in Singapore, „Applied Economics”, vol. 43, iss. 29, DOI 10.1080/00036846.2010.493140.

van de Woestyne M., Dewettinck K., van Bruystegem K. 2010 Human Resource Challenges for Small Growing Companies in Flanders, „Global Business and Organizational Excellence", vol. 29, iss. 4, DOI 10.1002/joe.20327.

Veum J.R. 1995 Sources of Training and Their Impact on Wages, „Industrial and Labor Relations Review", vol. 48, no. 4, DOI 10.1177/001979399504800413.

Wright P.M., Gardner T.M., Moynihan L.M., Allen M.R. 2005 The Relationship Between HR Practices and Firm Performance: Examining Causal Order, „Personnel Psychology”, vol. 58, iss.2, DOI 10.1111/j.1744-6570.2005.00487.x. 